\title{
Barriers To Online Postsecondary Education Crumble: Enrollment In Traditional Face- To-Face Courses Declines As Enrollment In Online Courses Increases
}

\author{
Dahli Gray, Walden University, USA
}

\begin{abstract}
Contrary to expectations, total postsecondary enrollment in the United States (US) declined in Fall 2011. In fact, it continues to decline while online enrollment continues to increase. Students can more easily cross geographic boundaries as online access causes barriers to postsecondary education to crumble, and more than 50\% of the demand for online learning is currently met by non-US providers. Therefore, a major opportunity exists for US educational institutions to grow enrollment by effectively meeting demand for online postsecondary learners globally.
\end{abstract}

Keywords: Postsecondary Education; Online Classes; Virtual Universities; Education Enrollment

\section{INTRODUCTION}

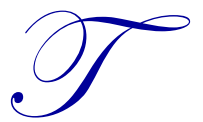

he landscape of online post-secondary learning, as an industry, is changing faster than existing postsecondary educational institutions are evolving to keep up. With total postsecondary enrollment declining as of Fall 2011 (Allen \& Seaman, 2013) and online enrollment continuing to increase (Martin, 2013), there is motivation for educational institutions to change more quickly. This paper considers this evolving situation and the opportunities for postsecondary institutions in more detail and includes some key vocabulary.

\section{DEFINITIONS EVOLVE}

Distance education initially referred to teaching and learning that happened outside of the geographic (place-based) campus; traditionally, distance interaction between student and teacher occurred via postal mail. Distance education in the $21^{\text {st }}$ century, in contrast, takes place online. Traditional non-online face-to-face education is no longer adequate; in fact, software, such as Skype, has allowed online learning to include a face-to-face component, even at a distance. Thus, the relevant distinction is no longer between distance and face-to-face, but between online and brick-and-mortar learning. Online learning allows the teacher and the learner to interact from any place(s) with Internet access, while non-online classrooms are restricted to specific places. This is why nononline classrooms and learning are now referred to as brick-and-mortar, place-based, or non-online. In the next section, enrollment is discussed.

\section{TOTAL ENROLLMENT DECLINES AS ONLINE ENROLLMENT INCREASES}

Projections for levels of online enrollment in US institutions have been made based on prior experience. For example, Walton-Radford, and Weko (2011) report that "from 2000 to 2008, the percentage of undergraduates enrolled in at least one distance education class expanded from 8 to 20 percent" (p. 3). If the past predicts the future, then the following statement from the US National Center for Education Statistics (NCES, 2012) is consistent with the conclusions presented by Walton-Radford, and Weko: "College enrollment was 21.0 million in Fall 2010, higher than in any previous year ... [and] is expected to continue setting new records from Fall 2011 through Fall 2020. Between Fall 2010 and Fall 2020, enrollment is expected to increase by 15 percent." 
However, overall college enrollment did not set a new record for Fall 2011. Allen and Seaman (2013) report that total enrollment decreased in Fall 2011 as compared to Fall 2010 (by 22,013 enrollments, representing a $.1 \%$ decrease), while online enrollment increased (by 572,512 enrollments, representing a $9.3 \%$ increase of online enrollments) (p. 36). Crucially, this means that non-online enrollments declined by 594,525 (i.e., 572,512 increase in online enrollments plus the overall decline in enrollments of 22,013). Table 1 provides details regarding total and online college enrollment.

Table 1: Total And Online Enrollment In Degree-Granting Postsecondary Institutions_Fall 2002 Through Fall 2011

\begin{tabular}{|l|c|c|c|c|c|c|}
\hline & $\begin{array}{c}\text { Total } \\
\text { Enrollment }\end{array}$ & $\begin{array}{c}\text { Annual } \\
\text { Growth Rate } \\
\text { of Total } \\
\text { Enrollment }\end{array}$ & $\begin{array}{c}\text { Students } \\
\text { Taking at } \\
\text { Least One } \\
\text { Online Course }\end{array}$ & $\begin{array}{c}\text { Online } \\
\text { Enrollment } \\
\text { Increase over } \\
\text { the Previous } \\
\text { Year }\end{array}$ & $\begin{array}{c}\text { Online } \\
\text { Annual } \\
\text { Growth Rate } \\
\text { of Online } \\
\text { Enrollment }\end{array}$ & $\begin{array}{c}\text { Enrollment as } \\
\text { a Percentage } \\
\text { of Total } \\
\text { Enrollment }\end{array}$ \\
\hline Fall 2002 & $16,611,710$ & NA & $1,602,970$ & NA & NA & $9.6 \%$ \\
\hline Fall 2003 & $16,911,481$ & $1.8 \%$ & $1,971,397$ & 368,427 & $23 \%$ & $11.7 \%$ \\
\hline Fall 2004 & $17,272,043$ & $2.1 \%$ & $2,329,783$ & 358,386 & $18.2 \%$ & $13.5 \%$ \\
\hline Fall 2005 & $17,487,481$ & $1.2 \%$ & $3,180,050$ & 850,267 & $36.5 \%$ & $18.2 \%$ \\
\hline Fall 2006 & $17,758,872$ & $1.6 \%$ & $3,488,381$ & 308,331 & $9.7 \%$ & $19.6 \%$ \\
\hline Fall 2007 & $18,248,133$ & $2.8 \%$ & $3,938,111$ & 449,730 & $12.9 \%$ & $21.6 \%$ \\
\hline Fall 2008 & $19,102,811$ & $4.7 \%$ & $4,6606,353$ & 668,242 & $16.9 \%$ & $24.1 \%$ \\
\hline Fall 2009 & $20,427,711$ & $6.9 \%$ & $5,579,022$ & 972,669 & $21.1 \%$ & $27.1 \%$ \\
\hline Fall 2010 & $21,016,126$ & $2.9 \%$ & $6,142,280$ & 563,258 & $10.1 \%$ & $29.2 \%$ \\
\hline Fall 2011 & $20,994,113$ & $-.1 \%$ & $6,714,792$ & 572,512 & $9.3 \%$ & $32 \%$ \\
\hline Tab & & & & & 32 \\
\hline
\end{tabular}

Table from Allen and Seaman (2013, p. 36).

Adkins (2013) reports and predicts the following:

There are more than 40 million online higher education students in the world that take one or more of their classes online as of February 2013. All of these students are participating in formal education programs. By 2017, 24.5 million higher education students in the US will be taking one or more of their classes online. What makes the US unique is that 4.4 million of these students will be taking all of their classes online by 2017. (p. 19)

Time will tell if the predictions are to be realized. Providers of online classes from institutions outside of the US are discussed in the next section.

\section{ONLINE DEMAND MET BY NON-US INSTITUTIONS}

Adkins (2013) concluded that with 40 million higher education students in the world taking one or more online classes and less than 10 million of them having been covered by the US data presented in Table 1 above, there remain over 75\% of online students in programs outside of the US. As Adkins (2013) concludes, outside of the US "an education revolution [is] underway [and] it is the inexorable move away from print textbooks and classroom instruction, with the most dramatic events occurring in Latin America, Africa, and Asia" (p. 19). This has come about despite the increasing recognition of the importance of online education in the US; Allen and Seaman (2013) report that in contrast to 2002, when less than 50\% of US higher education institutions viewed online education as critical to long-term plans, in 2012 nearly $70 \%$ viewed it as vital (p. 4).

The University of South Africa (UNISA) presents an example of how the demand for online higher education is being met in a developing economy. In 2005, UNISA made a commitment to open distance education (UNISA, 2013). The stated motivation of the African Virtual University (AVU) - UNISA's online initiative (AVU, 2013) - is to increase "... access to quality higher education and training through the innovative use of information communication technologies." Increasing access is in response to increasing unmet demand.

The regulatory framework of US-based institutions partially explains their inability to meet the global demand for online learning. Reindl (2013) concludes that "[t]he current patchwork of state regulations regarding online education poses challenges for states, institutions, and students" (p. 3). 


\section{DELIVERY MEDIUM CHANGES BUT US INSTITUTIONS DO NOT}

Adkins (2013) concludes the following:

The delivery medium in the global education industry is evolving very fast, but relative to the supply chain, there is no revolution afoot. The supply chain (comprised of buyers and sellers) is evolving slowly. Institutions across the globe are changing the way they deliver learning, but the institutions themselves are not undergoing fundamental change. It will be business as usual for the foreseeable future. (p. 19)

While established educational institutions are resisting fundamental change, online institutions (e.g., Phoenix University, AVU) are capturing a major market share of online education. With overall postsecondary enrollment declining (Martin, 2013), educational institutions must embrace fundamental change to assure their survival and achieve success. One possible approach is considered in the next section.

\section{MOOCs}

Massive open online courses (MOOCs) are free online courses available to everyone. A list of upcoming MOOC lectures is available at http://www.mooc-list.com/. Jacobs (2013) samples numerous MOOCs and grades them as a group, as summarized in Table 2.

Table 2: Massive Open Online Courses Graded

\begin{tabular}{|l|c|}
\hline \multicolumn{1}{|c|}{ Category Graded } & Grade \\
\hline Professors & B+ \\
\hline Convenience & A \\
\hline Teacher-to-student interaction & D \\
\hline
\end{tabular}

Jacobs reports that "the professor is, in most cases, out of students' reach, only slightly more accessible than the pope." This is of concern because, as Sull (2013) emphasizes, teacher-to-student interaction is vital for successful learning. Table 3 lists teacher behaviors that Sull concludes are vital to student learning in online classes.

Table 3: Teacher Behaviors That Improve Student Learning In Online Classes

\begin{tabular}{|l|}
\hline Respond to all student queries within 24 hours \\
\hline Be detailed and positive in comments on student work \\
\hline Respond to all-or nearly all—-student postings \\
\hline Steer discussion threads in the direction of students' professional needs \\
\hline Offer live chats on a weekly basis \\
\hline
\end{tabular}

The appeal and appropriateness of the MOOC are hotly debated (Lohr, 2013) and are certainly worthy of additional research. Those who believe that teacher-to-student interaction is vital to the learning process have questioned the value of the MOOC. At this point, MOOCs remain free and it might be argued that this is a case of one getting what one pays for.

\section{FUTURE RESEARCH}

Future research should include the exploration of MOOCs, as just discussed. Future research should also examine online education regulations that hamper existing institutions' ability to deliver online learning (Reindl, 2013, p. 3). Additional research could explore why faculty do not accept online education; Allen and Seaman (2013) report that in the US faculty acceptance of online education was still less than 50\% in 2012 (p. 40). There may be valid reasons for their reluctance to accept online education - an issue that will warrant additional research.

\section{CONCLUSIONS}

Postsecondary educational institutions will continue to expand the delivery of online learning as total enrollment declines and demand for online learning increases. Postsecondary education regulation in the US needs to be done on the national level, since the alternative is to deal with more than 50 regulating agencies (one for each 
state plus regional agencies). Non-US postsecondary educational institutions are providing online access to millions of students, and it may be found that learning concepts and techniques becomes more important than the specific educational institution that delivers them - a disadvantage for US institutions, which have built strong brands worldwide. From the perspective of students, the barriers to online learning are crumbling and students have more choices as to where to access learning opportunities.

\section{AUTHOR INFORMATION}

Dahli Gray earned her doctoral degree from the George Washington University and her master's degree from Portland State University. She has over 40 articles published in journals, such as the Journal of Accounting Education and the International Journal of Accounting Education and Research, and has given over 60 presentations at conferences in countries, including the United States, Mexico, and the United Kingdom. She has been a full-time faculty member at schools, including the University of Notre Dame and American University. In addition to being a contributing faculty member at Walden University, she is a certified public accountant, certified management accountant, and certified fraud examiner with her consulting firm. E-mail: dahli.gray@waldenu.edu

\section{REFERENCES}

1. Adkins, S. (2013, March). Ambient insight whitepaper: The 2012 boom in learning technology investment. Ambientinsight.com. Retrieved from: http://www.ambientinsight.com/Resources/Documents/AmbientInsight-2012-Learning-TechnologyInvestment-Patterns.pdf

2. African Virtual University (AVU). (2013). Introduction. Retrieved from: http://www.avu.org/AboutAVU/introduction.html

3. Allen, E. \& Seaman, J. (2013, January). Changing course: Ten years of tracking online education in the United States. Babson Survey Research Group and Qualong Research Group. Retrieved from: http://www.onlinelearningsurvey.com/reports/changingcourse.pdf

4. Jacobs, A.J. (2013, April 20). Two cheers for Web U! New York Times Retrieved from: http://www.nytimes.com/2013/04/21/opinion/sunday/grading-the-moocuniversity.html?ref=todayspaper\& $\mathrm{r}=0$

5. Lohr, S. (2013, March 25. Beware of the high cost of 'free' online courses. New York Times. Retrieved from: http://bits.blogs.nytimes.com/2013/03/25/beware-of-the-high-cost-of-free-online-courses/

6. Martin, A. (2013, January 10). Downturn still squeezes colleges and universities. New York Times. Retrieved from: http://www.nytimes.com/2013/01/11/business/colleges-expect-lower-enrollment.html

7. National Center for Education Statistics (NCES). (2012, May). Digest of educational statistics: 2011. NCES. Retrieved from: http://nces.ed.gov/programs/digest/d11/index.asp

8. Reindl, T. (2013, January). Regulating online postsecondary education: State issues and options. National Governors Association. Retrieved from: http://www.nga.org/files/live/sites/NGA/files/pdf/1301RegulatingOnlineBrief.pdf

9. Sull, E.C. (2013, January 31). Student engagement in the online classroom. The Chronicle of Higher Education. Retrieved from: http://chronicle.com/article/Student-Engagement-inthe/136897/?cid=ja\&utm_source=ja\&utm_medium=en

10. University of South Africa (UNISA). (2013). Unisa history timeline. UNISA. Retrieved from: http://www.unisa.ac.za/140/index.php/unisa-history-timeline/

11. Walton-Radford, A. \& Weko, T. (2011, October). Learning at a distance: Undergraduate enrollment in distance education courses and degree programs. U.S. Department of Education. Retrieved from: http://nces.ed.gov/pubs2012/2012154.pdf 